\title{
Clarice Lispector e os romances da escuta
}

Nayana Moreira Moraes ${ }^{\mathrm{i}}$

\section{RESENHA}

LIBRANDI, Marília. Escrever de ouvido: Clarice Lispector e os romances da escuta. Traduzido por Jamille Pinheiro Dias e Sheyla Miranda. Belo Horizonte: Relicário, 2020.

Em dezembro de 2020 - mês e ano do centenário de Clarice Lispector - a editora Relicário lançou no Brasil o livro Escrever de ouvido: Clarice Lispector e os romances da escuta, da brasileira Marília Librandi. O projeto originalmente escrito em inglês, foi publicado em 2018 pela University of Toronto Press, período em que a pesquisadora lecionava na Universidade de Stanford. Traduzido para o português por Jamille Pinheiro Dias e Sheyla Miranda, o texto de Librandi explora as ressonâncias da prosa clariciana sob a perspectiva da escuta.

Os três primeiros capítulos do livro trazem reflexões relacionadas a uma história auditiva na produção ficcional, sobretudo, no olhar atento ao movimento da escuta na tradição literária brasileira. O gênero romance, a partir de uma crítica sólida, é investigado pelo que a autora define como "romance da escuta" (título do terceiro capítulo), aludido em face aos escritores Machado de Assis e Guimarães Rosa. Já nos capítulos subsequentes, que correspondem do quarto ao sétimo, o livro aprofunda o tema central da escuta nos romances Perto do Coração Selvagem, Água Viva e A Paixão Segundo GH, de Clarice Lispector, que é caracterizada por Librandi como "uma ficcionista-filósofa, uma escritora-centaura" (2020, p. 55). Como resultado, desponta a pesquisa de uma corporeidade auditiva nos estudos literários.

O primeiro capítulo busca esclarecer os objetivos e vertentes do que a autora reforça enquanto estudo de um escutar no escrever (2020, p. 29). A partir de tal desdobramento, apresenta a produção de efeito da escuta na escrita, partindo de três conceitos fundamentais que serão retomados nos capítulos seguintes: 1- escrever de

\footnotetext{
${ }^{\text {i }}$ Mestra em Estudos Literários pela Universidade Federal de Viçosa (UFV). ORCID: https://orcid.org/0000-0002-4190-1177 | nnayana.moraes@ gmail.com
} 
ouvido; 2- romance da escuta; 3- ecopoética. Destaca-se a profusão de obras literárias brasileiras marcadas pelo processo de escuta na imediação de um sentido ao ouvido. É interessante perceber a posição indispensável dada ao ouvido enquanto objeto mudo. $\mathrm{Ou}$ seja, o ouvido é um receptor de manifestações da linguagem, um órgão de entrada de objetos sonoros: segundo Librandi, "O ouvido não produz linguagem” (2020, p. 32). O silêncio aparece como composição de uma escuta literária que foge de uma dicotomia tradicional entre a fala e a escrita, pois escrever de ouvido pressupõe a dinâmica turva entre som e silêncio. Librandi recorre às reflexões de Jean-Luc Nancy como investigação de uma ontologia centrada na escuta, ressaltando aspectos filosóficos dessa perspectiva que é evidenciada pela presença do "corpo ouvinte" do escritor.

O capítulo dois aproxima a escrita de ouvido de Clarice à poesia concreta de Augusto de Campos. É por meio do poema "O Pulsar" e o romance A hora da estrela (1977) que a análise comparativa traça o modo com que a morte figura um sentir estrelar. Isto é, a morte é o indizível do corpo em face a essa escuridão sonora e que encontra no texto a estrela enquanto metáfora. Algo que Librandi destaca pela morte da protagonista do romance, Macabéa. "Escrever de ouvido" pressupõe uma escuta que reverbera na composição literária, como a identificação de propriedades auditivas no que se refere à acústica do movimento da palavra. É o que a pesquisadora descreve ainda no segundo capítulo:

\footnotetext{
Na expressão "escrever de ouvido", que se assemelha a uma autodescoberta, Clarice abre as portas para um mundo ainda pouco explorado no universo literário impresso: o estudo das propriedades auditivas e acústicas da escrita, presentes não só no momento da criação ficcional, quando a escritora "ouve" vozes e as inscreve, mas também quando se lê em silêncio, quando um mundo imaginário desperta por meio das vibrações dos sons e imagens das palavras. Tomando literalmente a expressão "escrever de ouvido", e desdobrando a teia de suas metáforas musicais e auditivas, o objetivo deste estudo é descrever a forma que ela assume em prosa ficcional. (LIBRANDI, 2020, p. 70).
}

A identificação de uma história literária auditiva se expressa pela correspondência de uma língua falada no Brasil, que se desenvolveu por um modo de expressão capaz de entoar as múltiplas culturas do território nacional. Tal aspecto é discutido no livro a partir de abordagens teórico-críticas acerca dos poemas do Padre Antonio Vieira. Não obstante, as línguas ameríndias incorporadas ao Português brasileiro reforçam o que Librandi descreve como "escrita de ouvido pós-colonial" (2020, p. 77) que apareceria, mais 
precisamente, com Oswald de Andrade por um intercâmbio que ressoa da oralidade de línguas nativas.

O capítulo três aprofunda os aspectos narrativos sobre os romances da escuta. Apresenta-se - a partir da teoria do romance de Bakhtin - os ecos da prosa ficcional brasileira, especialmente, com Machado de Assis e Guimarães Rosa. A questão da escuta nos romances de Clarice estaria condensada no procedimento metaficcional que teria sido inaugurado em Memórias Póstumas de Brás Cubas, de Machado de Assis. Por conseguinte, a subjetivação de uma criação literária exposta no narrador masculino de $A$ hora da Estrela (1977), por exemplo, evidenciaria o processo de gestação, bem como a reflexão da voz narrativa que se encontraria na escrita.

A linguagem clariciana situa-se justamente por um testemunho do leitor à improvisação como se a criação ficcional fosse a libertação de uma determinada estrutura formal, estando condicionada ao "momento em que se escreve". Librandi enfatiza o caráter performático da narrativa da escritora a partir daquilo que será sua intrínseca marca:

\footnotetext{
Clarice sintetiza aquilo que será o traço distintivo de suas últimas obras: textos em fragmentos, que depois são unificados e retrabalhados, mas sem perder o frescor, a vivacidade e a imediatez da experiência vivida. É aí que a improvisação começa a ser cada vez mais mencionada em suas obras, juntamente com o conceito de escrita de ouvido. Na trilha de Clarice, sugiro a possibilidade de definir a improvisação como um ato de atingir um estado ideal, no qual a impressão (sensorial, física, corporal) possa imediatamente se tornar expressão (simbólica e artística), para que (utopicamente) não haja separação entre o que se vê e o que se pinta, o que se diz e o que se escreve, o que faz barulho e o que se ouve. (LIBRANDI, 2020, p. 102).
}

Apresenta-se a noção de duplicação da autoria, que aparecerá no que é denominado pela pesquisadora, de romance da escuta. Trata-se de um diálogo direto com o leitor como se o livro fosse construído ao mesmo tempo em que é lido (2020, p. 104). O que ocorre é a interação entre o narrador e aquele que lê, estando este justaposto por esta escuta. Ou seja, há uma articulação entre a fala e a audição. É identificado no romance Dom Casmurro (1899), por exemplo, a fluidez da improvisação que será uma característica nas obras do Machado e que aparecerá também em Guimarães Rosa. Nesse sentido, os autores seriam atravessados pela escrita borbulhante cujo texto estaria sujeito aos sons e reverberações incontroláveis de seu narrador. 
Já o capítulo quatro investiga o romance inaugural de Clarice Lispector, Perto do Coração Selvagem (1943). Busca-se relacionar uma linguagem onomatopaica ao som da máquina de escrever. Joana, a protagonista do romance, seria o duplo da própria Clarice que se entrelaçaria aos acontecimentos da narrativa, como a orfandade. A morte da mãe, quando Joana ainda era criança, é muito semelhante à perda materna da escritora. O que se apresenta é o estágio de libertação literária que irá culminar no desprendimento ao gênero textual e sexual justamente para atingir o neutro (2020, p. 126). Elemento que ressoaria mais profundamente no it de Água Viva (1973).

Librandi chama atenção para a orelha à escuta de Perto do Coração Selvagem a partir das figurações que o texto apresenta. Destaca o caráter de correspondência entre a arte pictórica de Van Gogh e a exuberância sonora elucidada a partir de um sentido às flores mortas. O que o livro nos apresenta é a recusa de Clarice à instituição da arte formal enquanto missiva à expressão "radiante" que adquire importância na pintura do artista. Por meio da orelha decepada há a mediação do gesto sacrificial que seria a fonte da radiância da criação; aqui apresentada pela leitura de Bataille. Tal colocação converge com a prosa moderna da escritora e sua procura pelo inominável.

No mesmo capítulo, estabelece possíveis relações quanto a imagem do girassol na obra de Clarice e na pintura de Van Gogh. A referência simbólica ao nascimento expressa o aspecto que revigoraria o vínculo entre o ser e o girassol enquanto interstício da vibração. Aponta-se ao processo de escrita da escritora que irá acentuar as nuances de não nomeação da palavra. Trata-se de um modo de escrita de Clarice que busca não categorizar o objeto que permanece na incompletude, pois toda nomeação seria um ato de amputação. "Clarice escreve não para acrescentar nomes, mas para retirá-los, pois, ao definir, o nome retira das coisas sua potencialidade e, pode-se dizer, sua liberdade de ser qualquer ou nenhum nome" (2020, p. 153). Algo que Librandi perpassa acerca do "figurativo do inaudível" que, concomitantemente, compara ao "figurativo do inominável" de Água Viva (1973).

Em Perto do Coração Selvagem vemos a "abstração da figura do inaudível" (2020, p. 167) vista enquanto ruído da mulher diante da máquina de escrever. Essa observação estaria atrelada a enunciação da escrita clariciana que busca captar os timbres, o murmúrio e a entonação da "mulher da voz" (2020, p. 170). Nesse sentido, o livro de Librandi nos direciona ao capítulo seguinte, intitulado de “Objeto Gritante". 
O capítulo cinco se inicia pela continuidade da reflexão acerca da máquina de escrever e suas interpelações sobre o romance Água Viva. A relação da orelha com a escrita se intensifica por um modo particular de desautomatização do aparelho em que se digita. Argumenta-se, pelas prerrogativas teóricas de Friedrich Kittler, a eliminação de um modelo romântico de autoria, o que implica no favorecimento ao ouvido ante à máquina. Librandi recorda que a própria Clarice datilografava seus manuscritos e revela passagens de Água Viva que se fundem pela dinâmica entre a mulher-narradora e a máquina. O que se apresenta é a ampliação do objeto gritante, tornando-se a experiência do ato da escrita:

(...) temos assim uma explicação do termo objeto gritante e de sua origem: o objeto gritante é ao mesmo tempo a máquina de escrever e a escrita que surge a partir da relação simbiótica entre a escritora e a máquina, as duas typewriters da formulação de Kittler. O resultado é uma forma de escrita que escuta e ouve surdamente o grito mudo Por isso, diz-se "silêncio e leve espanto". (LIBRANDI, 2020, p. 188).

Vale ressaltar que Objeto Gritante era um dos títulos originais de Água Viva cuja versão final submeteu-se a um enxugamento no número de páginas e, também, na opção da escritora em convergir para uma produção ficcional. Em sua primeira versão, a obra teria recebido o título de Atrás do pensamento (1970). O final do capítulo se dirige a própria linguagem da escritora enquanto fruto de uma vibração corporal ao bater a máquina de escrever. Não obstante, apresenta a expressão de Kittler sobre o nascimento de uma literatura datilografada que seria justamente a literatura moderna. Em Água Viva identifica-se o aparato da escrita por meio da narradora e sua voz fonte de respiração literária.

O capítulo seis se propõe a refletir sobre o termo ecopoética e suas inferências sobre o romance A Paixão Segundo GH (1964). Trata-se de compreender as formas de emancipação daquele que se anuncia, ou seja, do seu narrador. Segundo Librandi, a narradora GH reproduz sons mudos que se instalam mediante ao outro que ressoa (2020, p. 212). A ecopoética visa a posição receptiva do Eco, discutido a partir da definição de Jean-François Lyotard. Para situar o romance pelo caminho de um texto mítico, o capítulo percorre a tradição de As Metamorfoses, de Ovídio, e suas interpelações à luz da perspectiva filosófica. A reflexão perpassa pela apropriação da linguagem e o sentido que ela nos impõe, sendo essa a condição da ninfa Eco em Narciso. 
É abordado, no final do capítulo, a organização de uma estrutura em eco no romance, pois procura-se não somente uma metáfora, como também o eterno retorno da palavra. "De fato, A Paixão se organiza de acordo com a estrutura de um eco - as palavras finais de cada capítulo são as primeiras do segmento seguinte, criando um canal de transmissão, um eterno retorno" (2020, p. 233). A ressonância se instaura sob um fundo de silêncio onde o eco se transforma em reverberação interior. Segundo Librandi, em GH, trata-se de uma experiência muda que cintila a metamorfose da narradora. Algo feito em face da relação com a barata de A Paixão Segundo $G H$ e pela mutabilidade da linguagem impulsionada pelo ouvido.

Por último, no capítulo que encerra o livro, ocorre a mediação simbólica entre o processo de escrita de Clarice - a partir da forma e do movimento que a palavra adquire - e a descrição de uma "língua-animal a ser domada" (2020, p. 263). Desta forma, o que se aborda é a continuidade da reflexão quanto aos aspectos mitológicos de sua ficção, dando destaque à figura do cavalo. Daí surge, sobretudo, a escrita Centaura de Clarice, que Librandi apresenta ao leitor logo em sua introdução. A aproximação estreita com o Centauro desbrava a ideia de uma dupla enunciação como se não fosse possível destituir de sua prosa a correspondência entre a existência e a linguagem. Por fim, o livro de Marília Librandi ecoa a escuta literária de Clarice Lispector, especialmente, daquilo que ressoa em nós leitores.

\section{Referências}

ASSIS, Machado de. Memórias póstumas de Brás Cubas. 18. ed. São Paulo: Ática, 1992. Dom Casmurro. São Paulo: Saraiva, 2006.

BAKHTIN, Mikhail. Questões de literatura e estética: A teoria do romance. Trad. Aurora Bernardine. São Paulo: Unesp/Hucitec, 1990.

BATAILLE, Georges. Sacrificial Mutilation and the Severed Ear of Vincent Van Gogh. In: ___ STOEKL (Org.). Visions of Excess: Selected Writings, 1927-1939. Trad. Allan Stoekl. Minneapolis: University of Minnesota Press, 1985.

CAMPOS, Augusto de. O Pulsar. In: Viva Vaia. Poesia, 1949-1979. Cotia: Ateliê Editorial, 2001. 
KITTLER, Friedrich. Discourse Networks 1800/1900. Trad. Michael Metteer and Chris Gullens. Stanford: Stanford University Press, 1990.

Gramophone, Film, Typewritter. Trad. Geoffrey Winthrop-Young and Michael Wutz. Stanford: Stanford University Press, 1999.

LISPECTOR, Clarice. Perto do Coração Selvagem. Rio de Janeiro: Rocco, 1998. A Paixão Segundo G.H. Rio de Janeiro: Rocco, 1998. Água Viva. Rio de Janeiro: Rocco, 1998. . A Hora da Estrela. Rio de Janeiro: Rocco, 1998.

LYOTARD, Jean-François e THÉBAUD, Jean-Loup. Just Gaming. Trad. Wlad Godzich. Minneapolis: University of Minnesota Press, 1985.

NANCY, Jean-Luc. À escuta. Trad. Fernanda Bernardo. Belo Horizonte: Edições Chão da Feira, 2014.

OVÍDIO. As Metamorfoses. Trad.: David Jardim Júnior. Rio de Janeiro: Ediouro, 1983. 